\title{
Morphological Aspects of Spermatogenic Cells at Different Stages of Sexual Maturation in Black Isogenic C57BL/6/Uni Mice
}

\author{
Aspectos Morfológicos de las Células de la Espermatogénesis en Diferentes \\ Etapas de Maduración Sexual del Ratón Negro C57BL/6/Uni
}

${ }^{*}$ Martins, M. R. F. B.; "Silva, P. J. R.; ${ }^{* *}$ Martins,B. B.; ${ }^{* * *}$ Zoca, S. M.; ${ }^{* * *}$ Freitas, M. A. \& ${ }^{* * *}$ Batista, T. C.

MARTINS, M. R. F. B.; SILVA, P. J. R.; MARTINS, B. B.; ZOCA, S. M.; FREITAS, M. A. \& BATISTA, T. C. Morphological aspects of spermatogenic cells at different stages of sexual maturation in black isogenic C57BL/6/Uni mice. Int. J. Morphol., 30(1):290$295,2012$.

SUMMARY: In order to study the morphological changes that occur in cells of the testes of isogenic black mouse C57BL/6/Uni into three periods during spermatogenetic used 15 mice divided into 3 groups of 5 animals with 40, 50 and 60 days of age. The mice were sacrificed and weighed. Then weighed and measured the testicles, to be processed finalmete histologically and stained with HE, PAS and Masson Massom-H and evaluated under light microscopy. Was observed in group I with 40 days of age in the seminiferous tubules had a lumen with sparse small amount of interstitial tubular cells. In the seminiferous epithelium were identified type A spermatogonia, intermediate and B, which occupied the compartment adbasal and intermingled with these cells was observed in spermatocytes I in Pachytene and leptotene, whereas in the adluminal compartment Golgi phase spermatids observed in the presence of acrosomal granule. In group II, the cells of the seminiferous epithelium were developed and it was observed in round spermatids cephalic hood phase plus many elongated spermatids in acrosome phase and Sertoli cells. In Group III, 60 days old, it was found that the seminiferous epithelium which was of the tubules had elongated spermatids in acrosome phase and maturation, with elongated nuclei and acrosomal system typical of spermiation in the presence of sperm and residual bodies near the tubular lumen. So you can check the morphological evolution of germ cell testicular spermatids and recognize its four phases: Golgi, cap, acrosome and maturation over the age of the animal.

KEY WORDS: Spermatogenesis; Mouse; Testes.

\section{INTRODUCTION}

Spermatogenesis consists of a long cellular development process of the seminiferous epithelium, by which spermatogonial stem cells turn into spermatozoids. In this process different phases are considered: Spermatogonial Phase, in which spermatogonia undergo mitotic divisions, giving rise to primary spermatocytes (I Cytes), while ensuring their number through renewal. In the second phase, Spermatocyte Phase, there is a meiotic division in the production of spermatocyte cells, producing haploid spermatids. The third and final phase, Spermeiogenesis, the spermatids undergo important transformations and give rise to spermatozoa (Clermont, 1972; Orsi \& Ferreira, 1978).

Morphologically they are represented by at least three types of spermatogonia (gonias): Type A or "dusty", intermediate (In) and Type B or "crusty" (Leblond \&
Clermont, 1952). The general cytological characteristics of these cells as nuclear and cytoplasmic forms are reviewed by (Courot et al., 1970; Martins, 1993; Martins \& Silva, 2001).

The primary spermatocytes I are products of mitotic division of the last spermatogonia generation (B), representing germ cells that undergo meiotic division (Ortavant et al., 1977). The primary spermatocytes I appear in the preleptotene or "resting" stage (Leblond \& Clermont), characterized by the presence of dense nuclear chromatin. The leptotene stage, effectively marking the beginning of the meiotic prophase (Courot et al.), is characterized by an initial dispersion of chromatin crusts along the nuclear membrane, with a subsequent strong compaction of the chromatin filaments. These become condensed and polarized within the nucleus (Courot et al.; Orsi \& Ferreira).

\footnotetext{
* Universidade Estadual Paulista, Departamento de Anatomia, Botucatu - SP, Brasil.

** Universidade Estadual Paulista, Aluna de Graduação em Zootecnia , Botucatu - SP, Brasil.

**** Universidade Estadual Paulista, Alunos de Graduação em Medicina Veterinária, Botucatu - SP, Brasil.
} 
In the zygotene stage, which follows the leptotene, the homologous chromosomes are paired and thickened (Courot et al.); hence the chromatin material becomes more evident, with a configuration described as a "bouquet" of homologous chromosomes (Ortavant et al.). Next, in the pachytene stage, each chromosome is divided lengthwise into two chromatids, thus the chromosomes appear thickened (Ortavant et al.).

During pachytene, under light microscopy, the chromatin appears as thick and scattered filaments inside the nucleus for a long period of time, during which the nuclear and cell volumes progressively increase. These events are also a consequence of the short duration of the diplotene stage, during which the chromosomes separate. The nucleus then enters the metaphase, anaphase and telophase of the first maturation division, when the spermatocytes II are formed (Clermont).

Hypothetically, in the diplotene of prophase I the tetrads are constituted between the similar chromosomes and in the diakinesis, also difficult to characterize under light microscopy, the chromosomes are highly coiled and do not bind to each other, except for the chiasm (Courot et al.).

The interphase nucleus of spermatocytes II appears smaller than the primary spermatocytes in late pachytene, exhibiting a granular chromatin, slightly colored, and also globular and chromophilic chromatin freely arranged in the nucleoplasm or adhering to the nuclear membrane. These cells have a short duration and quickly enter the second maturation division, without duplication of its DNA, resulting in haploid spermatids (Clermont).

The main stages in the development of spermatids, which characterize the Spermeiogenesis, have been described by several authors in different mammals, at light microscope level (Clermont). In rodents, including in white mice (Leblond \& Clermont) and in isogenic black mice (Martins, 1993, 1999; Martins \& Silva, 2001, 2005), and also in other mammals, (Ortavant et al.; Orsi \& Ferreira; Persona \& Bustos-Obregón, 1983; Suswillo \& Watson, 1990), the different stages and phases of the spermiogenetic process are characterized by optical microscope. The stages are numbered in progressive Arabic numerals and the phases are defined as Golgi, cephalic cap, acrosome and maturation.

The elaborate morphogenesis process of spermatids, which leads to differentiating the sperm, are collectively known as the kinetics of spermatogenesis, in which morphogenetic and morphological differentiation of seminiferous cells are observed (Orsi \& Ferreira; Martins et al., 1995).
Among the unique spermatid events during Spermeiogenesis, for the final sperm formation, the evolution of the Golgi apparatus (GA) stands out, which leads to differentiating the acrosome as a secretory organelle (Orsi et al., 1990). The development of the acrosome during mammalian Spermeiogenesis is well documented by Leblond \& Clermont, Bedford \& Nicander (1971) and Maxwell (1982). However, the ultrastructure of the acrosome has been thoroughly evaluated and described in the Chinese hamster, mouse, rat and rabbit by Phillips (1972), and in the isogenic black mouse by Martins \& Silva (2005).

The acrosome is known to contain hydrolytic enzymes, which have the ability to digest the material of the pellucid zone of the oocyte, enabling the fusion of the pronuclei of both gametes (Phillips; Orsi et al.).

The purpose of this study is to describe some remarkable morphological characteristics, which may recognize spermatogenic cells of the isogenic black mouse in the different evolution phases of the Spermeiogenesis process.

\section{MATERIAL AND METHOD}

In this work 15 male mice of the C57BL6 lineage Uni (40, 50 and 60 days old) were used. The animals were from the Central Animal Facility of UNICAMP, which were transferred to the vivarium of the Anatomy Department at the State University "Júlio de Mesquita Filho", Botucatu Campus. The animals were kept under controlled temperature conditions, maintaining the seasonal characteristics.

The animals were weighed on an "Owa Labor" scale and then sacrificed under anesthesia using MERCK diethyl ether by inhalation. Next, the testicles were removed from the abdominal cavity after laparotomy in the pubic area. The migration of the testes into the abdominal cavity was achieved by massaging the scrotal skin in the caudal-cranial direction. This maneuver was possible because of the size of the hamster's inguinal path, in all ages.

Bouin was the fixative chosen for this study, according to specifications by McManus \& Mowry (1960).

Once isolated, the testes were pre-fixed for about 30 minutes, as these are organs difficult to fix. After this period, the testes were removed and placed on absorbent paper to remove excess fixative and were then weighed in a Mettler analytical balance, accurate to two decimal places, in grams. 
Next, sagittal and cross sections of the testes were carried out, which were again immersed in fixative solution for 24 hours. After this step, the specimens were washed several times in $70 \%$ alcohol.

After fixation and sectioning, the material was dehydrated in increasing concentrations of alcohols, cleared in xylene (three changes) and embedded in paraplast, as specified by Romeis (1928) and Behmer et al. (1976). For paraffin embedding, the segments are oriented to obtain transverse and longitudinal histological sections, in relation to the longest axis of the testicle, taking into account the macroscopic sections, previously carried out.

The microtome consisted of a series of 5 to 7 micronthick sections. The microtome used was a Reichert-Jung, mod. 1130/Biocut. The sections were stretched in gelatinbichromate solution at $40^{\circ} \mathrm{C}$ and were histologically fixed on slides of $26 \times 76 \mathrm{~mm}$. These were then placed in an oven at temperatures between $58^{\circ} \mathrm{C}$ and $60^{\circ} \mathrm{C}$ for 6 hours, for sufficient distention of the sections.

The histological sections were deparaffinized, hydrated and then subjected to histological and histochemical staining methods in order to study and describe the cellular and tissular evolution stages, at light microscopy level, on the seminiferous epithelium. The histological and histochemical methods used were: hematoxylin and eosin (HE), Mallory's Trichrome and Massom's Trichrome and Pas-Hematoxylin.

\section{RESULTS AND DISCUSSION}

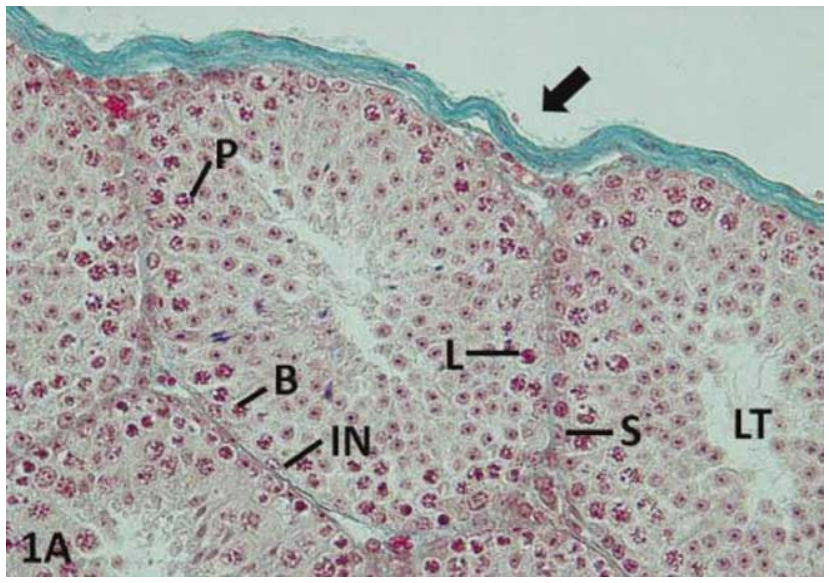

Similar to that described by Martins (1993), Martins \& Silva (1995), for the isogenic black mouse, during the spermatogenetic process of the C57BL6J/Uni mouse, the maturation of different cell types that make up the seminiferous epithelium, with aging, was observed. The cells observed in the seminiferous epithelium lining the seminiferous tubules in isogenic black mice were the Sertoli cells and the spermatogenetic cells. Among the spermatogenetic cells, the spermatogonia (gonias) A, intermediate (In) and B were located near the basal membrane, for which the longest axis of these cells is parallel (Figs. 1A and 1B). First-order spermatocytes were also observed (cytes I) in different stages of the long prophase I of the first meiotic division, the second order spermatocytes (cytes II) and round and elongated spermatids (tides).

The morphological evolution of testicular germ cells in C57BL6J/Uni mice was similar to the corresponding cells in black isogenic mice, as reported in the studies by Martins (1993) and Martins \& Silva (1995), in white mice and in bull and boar described by Suswillo \& Watson. Thus, the characterization of these cells was possible due to the increased condensation of nuclear chromatin. The spermatogonia A exhibited oval nuclei, containing predominantly granular chromatin and one or the two evident nucleolus, adhered to the inner face of the nuclear membrane. As for the intermediate spermatogonia, their nuclei was more rounded, but also filled with granular chromatin, also showing flakes of heterochromatin along the nuclear membrane, which to some extent hindered recognizing the nucleolus. However, it was observed that they had an intermediate degree of chromatin condensation between the Gonias A, which precede them, and Gonias $\mathrm{B}$, which follow them. The latter ones, also known as

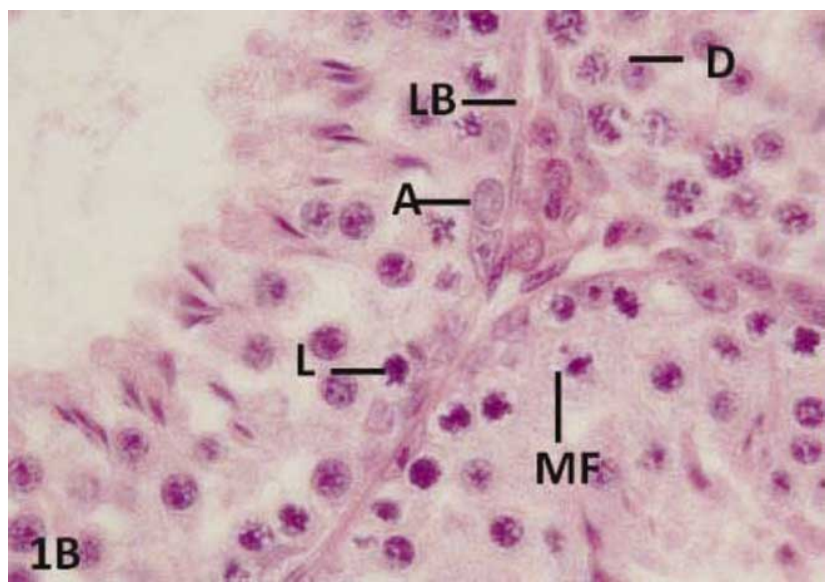

Fig. 1A: Cells of the seminiferous epithelium at 40 days. Indicated: Tunica albuginea (arrow), tubular lumen (TL), Sertoli cell (S), intermediate gonia (IN), gonia B (B), cytes I in Leptotene (L) and Pachytene (P). T. Masson, 40x. In B: basal lamina (BL), gonia A (A), cytes I in leptotene (L), diplotene (D), metaphase (MF) HE, 100x. 
Crusted Gonias, showed rounded and relatively smaller nuclei than those of Gonias A, and filled with heterochromatin flakes, which made it difficult to characterize the nucleolus. (Figs. 1A and 1B). These data are consistent with that described by Ortavant et al., which reported that the chromosome morphology differs in appearance at each spermatogonial division, which is stretched during the prophase of gonias A and smaller and contracted during the prophase of gonias B. They also reported that the duration of the DNA synthesis increases progressively from type A to type In, and from this to type B.

As described by Orsi \& Ferreira, Martins et al., still within the first meiotic division, following the Gonias type $\mathrm{B}$, the first-order spermatocytes emerge (Cytes I) in Leptotene, Zygotene, Pachytene and Diplotene (Figs. 1A, $1 \mathrm{~B}$ and $2 \mathrm{~A})$.

In Group I, at 40 days of age, we observed that the seminiferous tubules had a small tubular lumen, and that the interstitial cells appeared in small quantities. Occupying an adbasal position on the seminiferous epithelium, the nuclei of spermatogonia A, intermediate, and B were observed; and interspersed with the nuclei of these cells and in close proximity to the basal lamina, we observed the nuclei of Sertoli cells, predominantly pyramidal shaped, and a single and centralized nucleolus. In an intermediate location in the seminiferous epithelium, the nuclei of spermatocytes I were observed in Leptotene and Pachytene, whereas in the adluminal compartment, it was marked by the presence of round spermatids in the Golgi phase, which exhibited the idiosoma with the pro-acrosome granules at one of the ends of the nucleus (Figs. 1A and 1B). These results are consistent with those reported by Martins \& Silva (2001), which studied the ultrastructure of the spermatogonias and primary spermatocytes in isogenic mice.

In the second group, where the animals were 50 days old, the seminiferous epithelium was marked by the presence of spermatids in the cephalic cap stage, and by a new generation of elongated spermatids, predominantly given by the morphology of their elongated nucleus and coated by acrosome, the spermatids in acrosome phase and Sertoli cells (Figs. 2A and 3B), as described by Leblond \& Clermont, which describe the evolution and development of the acrosome system of spermatids in rats.

In the third and last group of animals studied at 60 days old, it was observed that the seminiferous epithelium lining the seminiferous tubules, exhibited elongated spermatids in the maturation phase, their nuclei with very condensed nuclear chromatin, showing difficulty to detect the acrosomal rods. These cells were observed in close proximity to the cytoplasm of the Sertoli cells, or in a periluminal position with the flagellums facing the seminiferous tubular lumen, in a typical spermiation arrangement that characterizes the maturation stage and the presence of residual bodies (Figs. 3A and 3B).

Based on the descriptions made on the distinctive events of Spermeiogenesis in rats and mice, by Leblond \& Clermont and in mammals by Orsi et al., we identified the spermatids in four different phases: Golgi, cephalic cap, acrosomic and maturation. In the Golgi and cephalic cap phases, which comprise the first spermatogenetic stages, the spermatids appeared round, a morphology given by the predominantly spherical shape of their nuclei. The idiosoma is characterized in the Golgi phase of spermatids, formed by a set of polarized vesicles located at one nuclear end (Fig. 2B). In the spermatids in the cephalic cap, the acrosome bead expanded and sent two rods that covered the nuclear end (Figs. 2A and 2B). With the expansion of the bead a flattened structure and strongly PAS-positive was characterized: the cephalic cap, which preceded the acrosome, as detailed in an ultrastructural study of the spermatids in isogenic black mice by Martins \& Silva (2005).

The last steps of the spermatogenetic process have been thoroughly described by Clermont, Orsi \& Ferreira, Martins (1993) and Martins \& Silva (2005), and by us in the C57BL6J/Uni mice, where in the acrosome (Fig. 2B) and maturation (Fig. 3A) phase the spermatids appeared elongated. This morphology is predominantly given by the elongated shape of their nuclei, which are coated by acrosoma. The spermatids in the acrosomal phase showed PAS-positive nuclei as in the maturation stage, however, in this last phase, the nuclei were stained with greater intensity than in the acrosomal phase. The acrosoma in both phases was characterized as a double rod: the dorsal longer and the ventral shorter.

The spermatids in maturation phase exhibited their nuclei with very compacted nuclear chromatin, therefore appearing strongly stained by PAS- $\mathrm{H}$, and some difficulty in characterizing the acrosomal rods. The spermatid nucleus at this stage was seen in the intimacy of the seminiferous epithelium in close proximity to the apical cytoplasm of the Sertoli cells, or occupying a periluminal position with the flagellums facing the seminiferous tubular lumen (Fig. 3A). The latter configuration is typical of the spermiation process that characterizes the end of the maturation phase, which was evidenced in the animals at 50 days (Fig. 2A). 

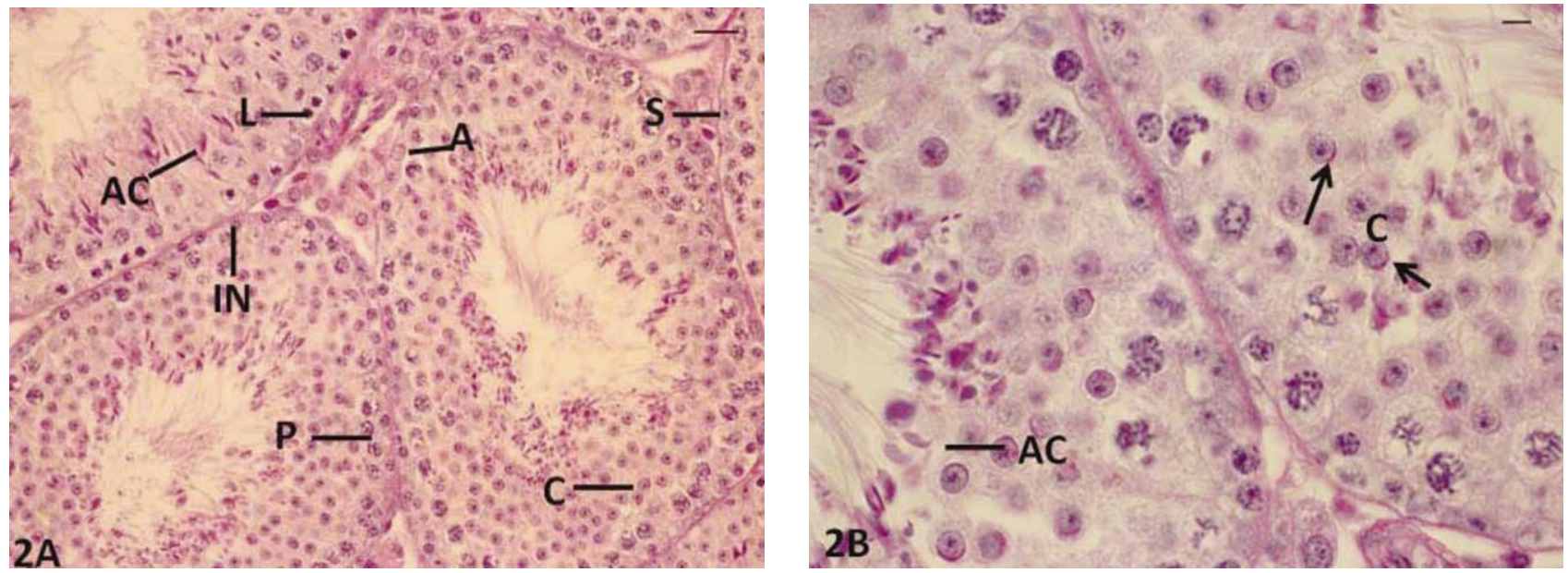

Fig. 2A: Cells of the seminiferous epithelium at 50 days. Indicated: gonia A (A), intermediate gonia (IN), rounded tides with cephalic cap (C), elongated tides in acrosomal phase (AC), cytes I in pachytene (P), cytes I in leptotene (L). PAS-H, 40x. In B: rounded tides with cephalic cap (C), elongated tides in acrosomal phase (AC). PAS-H, 100x.
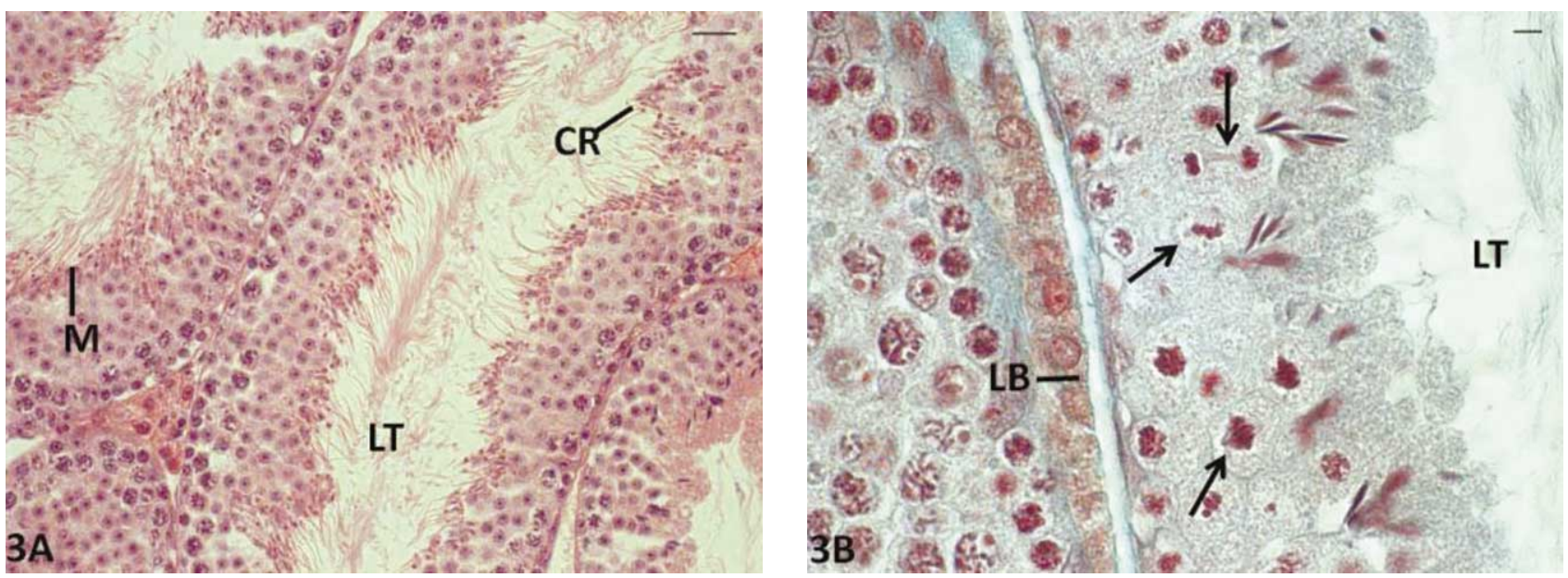

Fig. 3A: Cells of the seminiferous epithelium at 60 days. Indicated: Residual bodies (CR), tubular lumen (TL), elongated tides in maturation phase with their flagellum facing seminiferous tubular lumen (M). HE, 40x. In B: Tubular lumen (TL), Basal lamina (BL), Metaphase figures (arrow); end of cell division giving rise to two daughter cells (*). T. Masson, 100x.

\section{CONCLUSION}

In this study, we observed the morphological evolution of testicular germ cells in black isogenic C57BL/ 6/Uni mice and recognized the spermatids in its four phases: Golgi, Cephalic cap, Acrosomal and Maturation, throughout the age of the animals.

\section{ACKNOWLEDGMENTS}

We thank Mr. Alcides Carlos Lacerda e Marcos Alexandre Pavan for the technical support provided.
MARTINS, M. R. F. B.; SILVA, P. J. R.; MARTINS, B. B.; ZOCA, S. M.; FREITAS, M. A. \& BATISTA, T. C. Aspectos morfológicos de las células de la espermatogénesis en diferentes etapas de la maduración sexual C57BL/6/Uni isogénicas ratón negro. Int. J. Morphol., 30(1):290-295, 2012.

MARTINS, M. R. F. B.; SILVA, P. J. R.; MARTINS, B. B.; ZOCA, S. M.; FREITAS, M. A. \& BATISTA, T. C. Aspectos morfológicos de células de la espermatogénesis en diferentes etapas de maduración sexual del ratón negro isogénico C57BL/6/Uni. Int. J. Morphol., 30(1):290-295, 2012.

RESUMEN: Con el fin de estudiar los cambios morfológicos que ocurren en las células del testículo del ratón negro isogénico 
C57BL/6/Uni en tres períodos diferentes del proceso espermatogenético; fueron utilizados 15 ratones divididos en 3 grupos $(n=5)$ con 40, 50 y 60 días de edad respectivamente. Todos los animales fueron sacrificados y pesados. Posteriormente sus testículos se pesaron, midieron y procesaron histológicamente para HE, PAS y tricrómico Massom-H. Las muestras obtenidas fueron evaluados con microscopía de luz. En el grupo I con 40 días se observaron túbulos seminíferos con un lúmen pequeño y escaza cantidad de células intersticiales. En el epitelio seminífero se identificaron espermatogonias tipo A, intermedio y B, quienes ocuparon el compartimiento basal entremezclándose con espermatocitos I en paquiteno y leptoteno. En el compartimiento adluminal se observaron espermatidas de fase Golgi y presencia de gránulos acrosomales. En el grupo II de 50 días, se observaron células del epitelio seminífero desarrolladas, espermatidas en fase de capuz cefálico, muchas espermatidas elongadas en fase acrosomica y células sustentaculares. En el Grupo III de 60 días se observó el epitelio del túbulo seminífero con espermátidas alargadas en fase acrosómica y de maduración, con núcleos alargados y un sistema acrosomal típico de la espermiación, con presencia de espermatozoides y cuerpos residuales cerca del lúmen tubular. En conclusión se observa la evolución morfológica de las células germinativas testiculares y se reconocen las espermatides en sus cuatro fases: Golgi, capuchón, acrosomal y de maduración en las diferentes edades del animal.

PALABRAS CLAVE: Espermatogénesis; Ratón; Testículos.

\section{REFERENCES}

Bedford, J. M. \& Nicander, L. Ultrastructural changes in the acrosome and sperm membranes during maturation of spermatozoa in the testis and epididymis of the rabbit and monkey. J. Anat., 108(3):527-43, 1971.

Behmer, O. A.; Tolosa, E. M. C. \& Freitas de Neto, A. G. Manual de técnicas para histologia normal e patológica. São Paulo, Edart, 1976. p.240.

Clermont, Y. Kinetics of spermatogenesis in mammals: seminiferous epithelium cycle and spermatogonial renewal. Physiol. Rev., 52(1):198-236, 1972.

Courot, M.; Hochereau-de Reviers, M. T. \& Ortavant, R. Spermatogenesis. In: Johnson, A. D.; Gomes, W. R. \& VanDemark, N. L. The testis. New York, Acad. Press, 1970. pp.339-432.

Leblond, C. P. \& Clermont, Y. Spermiogenesis of rat, mouse, hamster and guinea pig as revealed by the periodic acid-fuchsin sulfurous acid technique. Am. J. Anat., 90(2):167-215, 1952.

Martins, M. R. F. B. Aspectos morfológicos da espermatogênese no camundongo (Mus musculus, L. Rodentia). O ciclo espermatogenético na variedade negra isogênica C57BL6J. Tese de Doutorado, Botucatu, Universidade Estadual Paulista, 1993.
Martins, M. R. F. B. Histochemical and structural characteristics of the testes of isogenic black mice (Rodentia: Muridae). Braz. J. Morphol. Sci., 16(1):5-9, 1999.

Martins, M. R. \& Silva, J. R. Ultrastructure of spermatogonia and primary spermatocytes of C57BL6J mice. Anat. Histol. Embryol., 30(3):129-32, 2001.

Martins, M. R. F. B. \& Silva, P. J. R. C. Ultrastructural Aspects of Spermatids in Isogenic Black Mouse C57BL6J. Int. J. Morphol., 23(4):323-8, 2005.

Maxwell, W. L. The acrosomal zonule. Tissue Cell, 14(2):283-8, 1982.

McManus, J. F. A. \& Mowry, R. W. Staining methods: histologic and histochemical. New York, P. B. Hoeber, 1960. p.140.

Orsi, A. M. \& Ferreira, A. L. Reexame do processo da espermatogênese em mamíferos principalmente em rato e gambá. Ciênc. Cult., 30:65-9, 1978.

Orsi, A. M.; Vicentini, C. A. \& Gregório, E. A. Considerações sobre a morfologia e morfogênese das espermátides de mamíferos. Rev. Ciênc. Bioméd., 11:73-80, 1990.

Ortavant, R.; Courot, M. \& Hochereau Reviers, M. T. Spermatogenesis in domestic mammals. In: Cole, H. H. \& Cupps, P. T. (Eds). Reproduction in domestic animals. 3rd ed. New York, Academic Press, 1977. p.665.

Persona, L. \& Bustos-Obregón, E. Seminiferous epithelium cycle in the armadillo. Arch. Androl., 10(2):113-8, 1983.

Phillips, D. M. Substructure of the mammalian acrosome. J. Ultrastruct. Res., 38(5):591-604, 1972.

Romeis, B. Guia formulário de técnicas histológica. Barcelona, Labor, 1929. p.722.

Suswillo, R. F. \& Watson, P. F. A new light microscopy classification of spermatogenesis in the bull and the boar applicable to tissues processed for electron microscopy. Anat. Histol. Embryol., 19(4):326-39, 1990.

Correspondence to:

Martins, M.R.F.B.

Universidade Estadual Paulista

Departamento de Anatomia

Botucatu - SP,

CEP: $18618-970$

BRASIL

E-mail: marcia@ibb.unesp.br

Received: 15-08-2011

Accepted: 12-12-2011 